March $2000 \quad$ • NREL/TP-520-27942

\title{
The Results of the First World Photovoltaic Scale Recalibration
}

\section{Keith Emery}

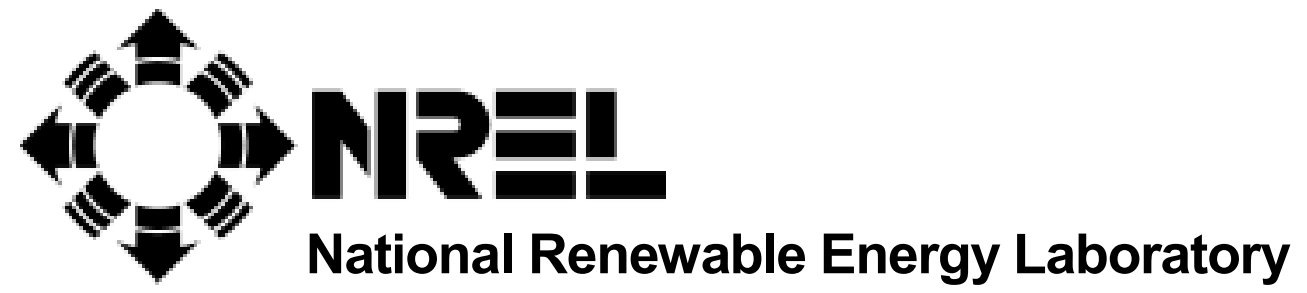

1617 Cole Boulevard

Golden, Colorado 80401-3393

NREL is a U.S. Department of Energy Laboratory

Operated by Midwest Research Institute $\bullet$ Battelle $\bullet$ Bechtel

Contract No. DE-AC36-99-G010337 
March 2000 • NREL/TP-520-27942

\section{The Results of the First World Photovoltaic Scale Recalibration}

\section{Keith Emery}

Prepared under Task No. PV00.3401

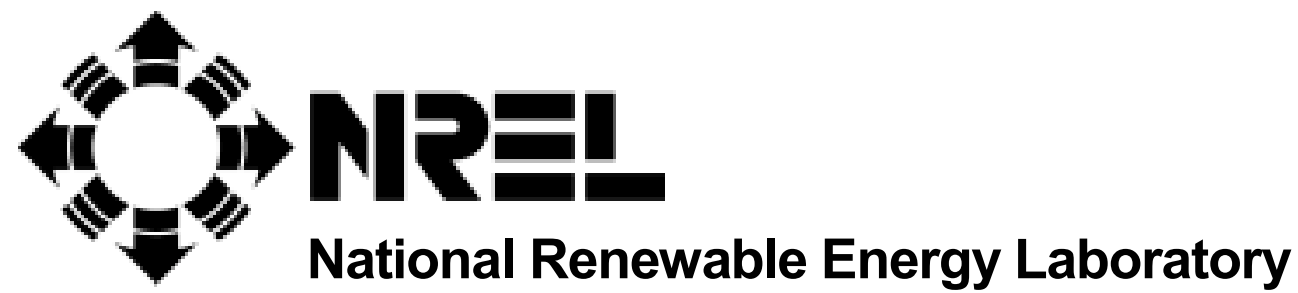

1617 Cole Boulevard

Golden, Colorado 80401-3393

NREL is a U.S. Department of Energy Laboratory

Operated by Midwest Research Institute $\bullet$ Battelle $\bullet$ Bechtel

Contract No. DE-AC36-99-G010337 


\section{NOTICE}

This report was prepared as an account of work sponsored by an agency of the United States government. Neither the United States government nor any agency thereof, nor any of their employees, makes any warranty, express or implied, or assumes any legal liability or responsibility for the accuracy, completeness, or usefulness of any information, apparatus, product, or process disclosed, or represents that its use would not infringe privately owned rights. Reference herein to any specific commercial product, process, or service by trade name, trademark, manufacturer, or otherwise does not necessarily constitute or imply its endorsement, recommendation, or favoring by the United States government or any agency thereof. The views and opinions of authors expressed herein do not necessarily state or reflect those of the United States government or any agency thereof.

Available electronically at http://www.doe.gov/bridge

Available for a processing fee to U.S. Department of Energy

and its contractors, in paper, from:

U.S. Department of Energy

Office of Scientific and Technical Information

P.O. Box 62

Oak Ridge, TN 37831-0062

phone: 865.576.8401

fax: 865.576.5728

email: reports@adonis.osti.gov

Available for sale to the public, in paper, from:

U.S. Department of Commerce

National Technical Information Service

5285 Port Royal Road

Springfield, VA 22161

phone: 800.553.6847

fax: 703.605.6900

email: orders@ntis.fedworld.gov

online ordering: http://www.ntis.gov/ordering.htm

Printed on paper containing at least $50 \%$ wastepaper, including $20 \%$ postconsumer waste 


\title{
The Results of the First World Photovoltaic Scale Recalibration
}

\author{
Keith Emery \\ National Renewable Energy Laboratory \\ National Center for Photovoltaics \\ Measurements and Characterization Division \\ PV Performance Characterization Team
}

\begin{abstract}
This report presents the results of primary reference cell calibrations conducted at NREL in October and November of 1998. Twenty World Photovoltaic Scale (WPVS) reference cells were calibrated along with six candidate WPVS reference cells. One of NREL's primary Si reference cells with a long calibration history was also calibrated at the same time. This report also documents the small difference when WPVS spectral responsivity and temperature coefficient data are used in the calibrations. The spectral model that was used at NREL to extend the measured spectral irradiance to cover the wavelength range of 300-4000 $\mathrm{nm}$ was substantially updated during this event and its effect on the calibration value is also presented.
\end{abstract}

\section{Acknowledgment}

This work was supported by the U.S. Department of Energy under contract number DEAC36-99GO10337. The assistance of W. Zaaiman at the European Solar Test Installation (ESTI) and L. Ottoson at NREL is acknowledged. The author also wishes to thank the owners of the WPVS primary reference cells at Sandia National Labs, Physikalisch Technische Bundesanstalt (PTB) in Germany, Japan Quality Assurance Organization (JQA) in Japan, Tianjin Institute of Power Sources (TIPS) in China, Fraunhofer Institute of Solar Energy in Germany, Indian Association for the Cultivation of Science in India, Laboratorie Central des Industries Electriques (LCIE) in France, and the National Institute of Metrology (NIM) in China. 


\section{Table of Contents}

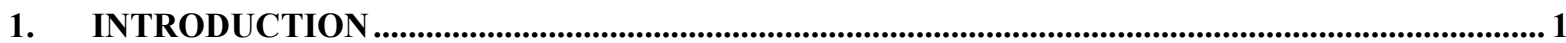

2. WORLD PHOTOVOLTAIC SCALE (WPVS) SAMPLE SET .......................................................... 1

3. REFERENCE CELL CALIBRATION PROCEDURES........................................................................ 2

4. WPVS ANALYSIS AND CALIBRATION VALUES ........................................................................... 4

4.1 EFFECT OF WPVS TEMPERATURE COEFFICIENT AND QUANTUM EFFICIENCY …..................................... 4

4.2 EFFECT OF UPDATED VERSUS PREVIOUS SPECTRAL MODEL ............................................................... 5

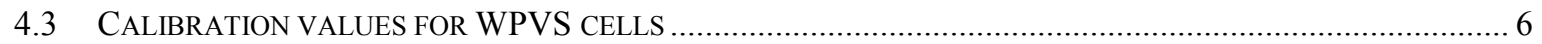

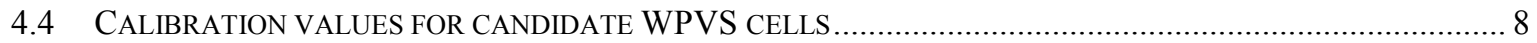

5. SUMMARY AND RECOMMENDATIONS ....................................................................................... 13

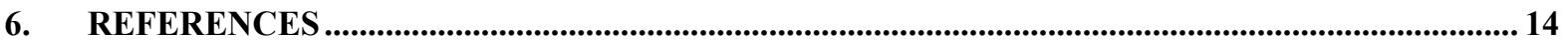




\section{Introduction}

The World Photovoltaic Scale (WPVS) was established after a formal international intercomparison was conducted during the 1993 to 1996 time period. The results of this intercomparison and the protocol for conducting recalibration were established [1-3]. Of the four WPVS qualified calibration facilities, Physikalisch Technische Bundesanstalt (PTB) in Germany; Japan Quality Assurance Organization (JQA) in Japan, Tianjin Institute of Power Sources (TIPS) in China, and NREL, NREL agreed to perform the first recalibration.

\section{World Photovoltaic Scale Sample Set}

The following WPVS sample set submitted by the participating organizations for calibration is listed in Table 1.

Table 1. The WPVS Sample Set Submitted for Recalibration.

(The asterisk on the cell identification denotes new cells submitted to be part of the sample set.)

$\begin{array}{lll}\text { Identification } & \text { Organization } & \text { Country } \\ 93308 & \text { JQA/ETL } & \text { Japan } \\ 93309 & \text { JQA/ETL } & \text { Japan } \\ 930216-1 & \text { NREL } & \text { U.S.A. } \\ 930216-2 & \text { NREL } & \text { U.S.A. } \\ 930417-1 & \text { LCIE } & \text { France } \\ 930417-2 & \text { LCIE } & \text { France } \\ \text { TDB9303 } & \text { TIPS } & \text { China } \\ \text { TDC9305 } & \text { TIPS } & \text { China } \\ \text { NIM9351 } & \text { NIM } & \text { China } \\ \text { NIM9352 } & \text { NIM } & \text { China } \\ \text { PX102C } & \text { ESTI } & \text { European Union } \\ \text { PX201C } & \text { ESTI } & \text { European Union } \\ \text { RS-69 } & \text { PTB } & \text { Germany } \\ \text { RS-78 } & \text { PTB } & \text { Germany } \\ \text { Y45 } & \text { Sandia } & \text { U.S.A. } \\ \text { Y124 } & \text { IACS } & \text { India } \\ 930318-5^{*} & \text { JQA/ETL } & \text { Japan } \\ 980512-1^{*} & \text { Sandia } & \text { U.S.A. } \\ 980512-2^{*} & \text { Sandia } & \text { U.S.A. } \\ \text { RS-06 } & \text { PTB } & \text { Germany } \\ \text { RS- } 07^{*} & \text { PTB } & \text { Germany } \\ \text { RS-12 } & \text { JQA/ETL } & \text { Japan }\end{array}$

Intermittent temperature and electrical connection problems were observed in the NIM (National Institute of Metrology in China) and TIPS samples similar to what was observed at NREL during the previous WPVS calibration. Several sample boxes were inadvertently 
shipped to the wrong organization. This was because of a lack of sample identification on the box. As in the previous WPVS calibration, the TIPS cells were mislabeled as IDB9303 and IDB9305. It was difficult to manage the reference cell cables during the recalibration because the corresponding reference cells for most removable cables were not identified on the cable. Some of the labeled cables had stickers identifying the wires that tended to slide off. Problems with cabling were further complicated because several of the cables were interchangeable and not compatible.

\section{Reference Cell Calibration Procedures}

Similar procedures and equipment used in the previous WPVS calibration at NREL were employed in this calibration [1-3]. The temperature control of the LICOR LI-1800 spectroradiometer was substantially improved with the replacement of a resistive heater for the detector and preamplifier operating at $40 \pm 0.5^{\circ} \mathrm{C}$, with a thermoelectric-controlled heater operating at $20 \pm 0.02^{\circ} \mathrm{C}$.

The calibration procedure involves measuring each cell's short-circuit current under natural sunlight simultaneously with the light's intensity and absolute spectral irradiance. The procedure's details are very similar to those presented in reference 4 . Four reference cells' short-circuit currents $\left(\mathrm{I}_{\mathrm{Sc}}\right)$ are measured simultaneously with active biasing to zero volts as shown in Figure 1.

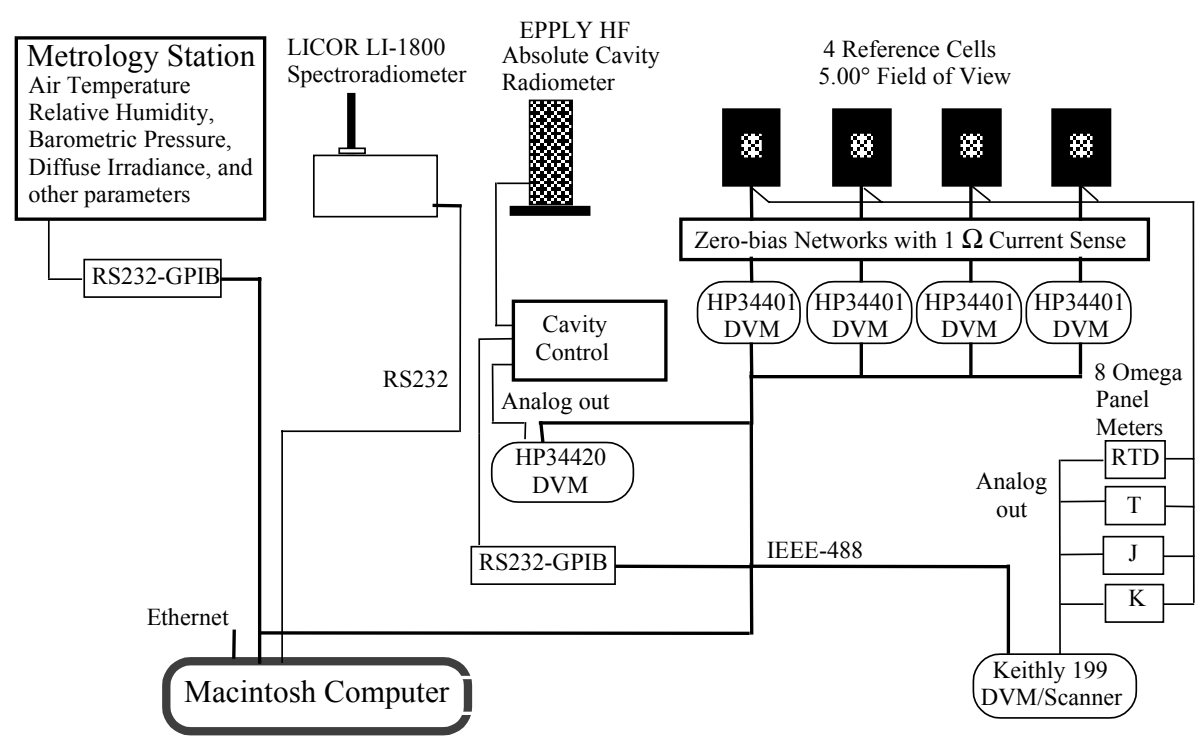

Figure 1. Block diagram of the NREL primary reference cell calibration facility [4].

Collimating tubes limit the field of view for the cells to $5.00^{\circ}$. The total irradiance ( $E_{\text {tot }}$ ) is measured by an absolute cavity radiometer with a $5.00^{\circ}$ field of view that is directly traceable to the World Radiometric Reference [5]. A LICOR model LI-1800 spectroradiometer with a 
$5.00^{\circ}$ field of view collimating tube measures the spectral irradiance $\left(E_{S}(\lambda)\right)$ between 350 and $1100 \mathrm{~nm}$. An atmospheric transmittance model uses this spectral information to compute the spectral irradiance from 305 to $4045 \mathrm{~nm}[4,8]$. The transmittance model was recently updated to include more accurate AM0 spectral irradiance and absorption coefficients [8]. Each instrument and the set of cells being measured is mounted to a separate tracker with a line-frequency time base. The accuracy of the tracking is periodically verified by inspection.

Each $\mathrm{E}_{\mathrm{S}}(\lambda)$ measurement takes approximately 30 seconds. During that time, approximately $30 \mathrm{ISc}_{\mathrm{Sc}}$ and $\mathrm{E}_{\text {tot }}$ readings are collected with temperature data to complete a data set. Sets with an $\mathrm{I}_{\mathrm{SC}} / \mathrm{E}_{\text {tot }}$ range exceeding $0.5 \%$, or standard deviation exceeding $0.1 \%$, are rejected. Sets with an $\mathrm{E}_{\text {tot }}$ range greater than $0.5 \%$ are rejected as well.

The $\mathrm{I}_{\mathrm{sc}}$ for each set of data is corrected to $25^{\circ} \mathrm{C}$ using the WPVS assigned temperature coefficient [3]. The WPVS quantum efficiency was used in the computations. Spectral correction is applied using the cell's relative spectral response, the spectral irradiance derived from the atmospheric transmittance model $\left(\mathrm{E}_{\mathrm{Sm}}(\lambda)\right)$, and the global normal reference spectrum listed in IEC standard IEC 60904-3 $\left(\mathrm{E}_{\mathrm{ref}}(\lambda)\right)$ as factors. Using this information, the calibration value, $\mathrm{CV}$, for each data set can be computed using:

$$
C V=\frac{I_{\text {sc }}}{E_{\text {tot }}} \cdot \frac{\int_{\mathrm{a}}^{b} E_{\text {ref }}(\lambda) \cdot S_{r}(\lambda) d \lambda}{\int_{a}^{b} E_{\text {ref }}(\lambda) d \lambda} \cdot \frac{\int_{a}^{b} E_{s m}(\lambda) d \lambda}{\int_{a}^{b} E_{s m}(\lambda) \cdot S_{r}(\lambda) d \lambda}
$$

Finally, at least three days worth of valid data with at least 10 sets per day are averaged to give the reported $\mathrm{CV}$ and standard deviation. The $95 \%$ confidence uncertainty limit for these measurements is estimated at $\pm 1 \%$ with the elemental uncertainties given in Table 2 [4].

\section{Table 2. Estimated Uncertainty in the Calibration Value Using NREL's Primary Reference Cell Calibration Procedure [4].}

\begin{tabular}{lll} 
Source & $\begin{array}{l}\text { Bias } \\
(\%)\end{array}$ & $\begin{array}{l}\text { Random } \\
(\%)\end{array}$ \\
\hline $\begin{array}{l}\text { Isc measurement } \\
\text { Isc time constants }\end{array}$ & 0.02 & $\overline{0.02}$ \\
Absolute cavity radiometer & 0.37 & 0.2 \\
Spectral correction factor & 0 & 0.13 \\
Temperature correction factor & 0 & 0.05 \\
Thermal offset voltages & 0.05 & 0.05 \\
& $\overline{0.37}$ & 0.05 \\
Total & $\overline{0.37}$ & 0.32
\end{tabular}


The absolute-cavity-radiometer model HF 23734 was recalibrated in October 1998 prior to the WPVS calibration and is documented in reference 5. The estimated $\mathrm{U}_{95}$ uncertainty for the 1998 absolute-cavity-radiometer calibration, with respect to the World Radiometric Reference, is $0.24 \%$ [5]. This calibration uncertainty was based upon a standard deviation of $0.06 \%$ for 66 measurements over a period of three days and compared against six cavity radiometers that have been to the Davos IPC-IVIII calibration [5]. The spectral correction factors varied from $-4 \%$ to $+0.4 \%$. The estimated uncertainty in the spectral correction factor may be unrealistically low, but is certainly below $0.2 \%$ for the accurate quantum efficiencies used in this study [6]. The temperature corrections varied from $\pm 0.35 \%$, depending on the air temperature and the thermal conductivity of the reference cell package with the temperature-controlled plate.

\section{WPVS Analysis and Calibration Values}

Calibration data was collected on the October 10, October 19, November 12, November 13, and November 15, 1998. The direct-beam total irradiance varied from 728 to $971 \mathrm{~W} / \mathrm{m}^{2}$. The ratio of plane-of-array diffuse to direct was typically $15 \%$. The cell temperatures were near the $25^{\circ} \mathrm{C}$ plate temperature for samples where the temperature could be well controlled. The temperatures of the other samples ranged from a low of $18^{\circ} \mathrm{C}$ to a high of $32^{\circ} \mathrm{C}$. The temperature-dependent quantum efficiency was not used in determining the temperature coefficient as recommended in the 1993 Photovoltaic Energy Project (PEP) final report [3]. Instead, the quantum efficiency at $25^{\circ} \mathrm{C}$ was used for measurements at NREL on the Spectrolab X25 solar simulator, along with the internal temperature sensor. The reference cell Y124 was sent to NREL in December 1999 after the U.S. sanctions on India were lifted. The WPVS cell's 930216-1 and Y124 were calibrated on December 23, 24, 27, and 30. The December 1999 calibration data for 930216-1 was $0.8 \%$ greater than the 1998 calibration data. The December 1999 data for 930216-1 was not used in computing the WPVS calibration value.

\subsection{Effect of WPVS temperature coefficient and quantum efficiency}

The four WPVS calibration laboratories used their own temperature coefficient and quantum efficiency data, not the WPVS data supplied in the final report [3]. If the 1993 WPVS calibration values supplied by NREL were based upon the WPVS temperature coefficients and quantum efficiencies, the calibration values would have decreased an average of $0.06 \% \pm$ $0.08 \%$. The maximum change in the WPVS calibration value would have been $0.21 \%$ and the minimum change $-0.08 \%$. These results are shown graphically in Figure 2 . The differences between NREL and the supplied temperature coefficients are negligible, and can be attributed to the light source that they were measured under. The temperature correction varied from a high of $+0.4 \%$ to a low of $-0.7 \%$. If sample TDB 9303 is not included, the temperature corrections varied by $\pm 0.4 \%$. This is because samples TDB 9303 and TDB 9305 have connectors that extend below the back surface, making temperature control problematic without an adapter plate. 


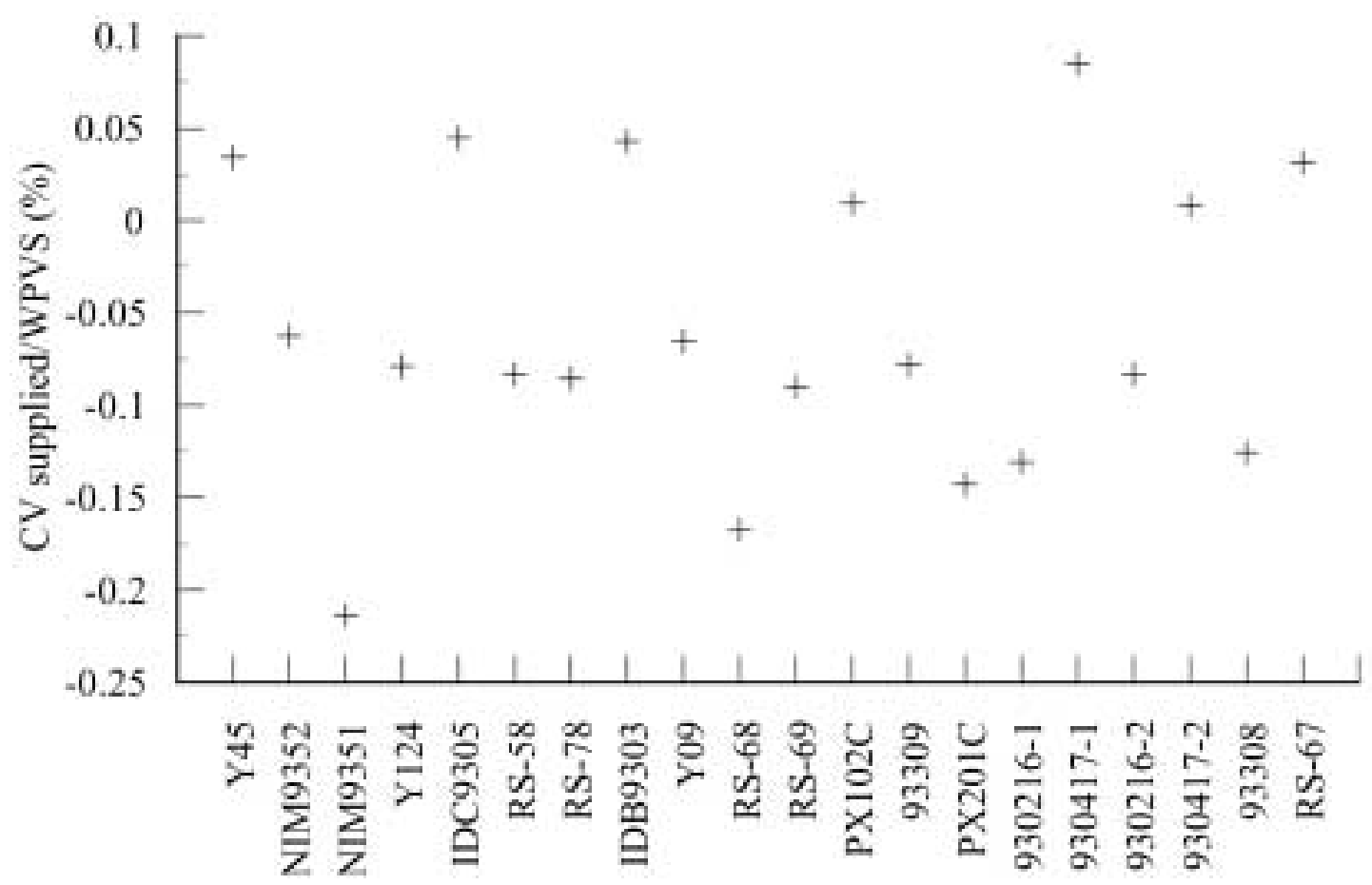

Figure 2. Comparison of the calibration value using the supplied versus the WPVS determined $\mathrm{I}_{\mathrm{sc}}$ temperature coefficient and spectral responsivity.

\subsection{Effect of updated versus previous spectral model}

The primary difference between the spectral model used in previous calibrations and the current calibration is the extraterrestrial source spectrum. The extraterrestrial spectrum recommended by the World Radiation Research Laboratory [7] had unrealistically low values in the 900 to $1000 \mathrm{~nm}$ region that were being used for the IR aerosol and water-vapor fit [8]. The effects of the new versus old model on the calibration value for the 1998 NREL recalibration are shown in Figure 3. 


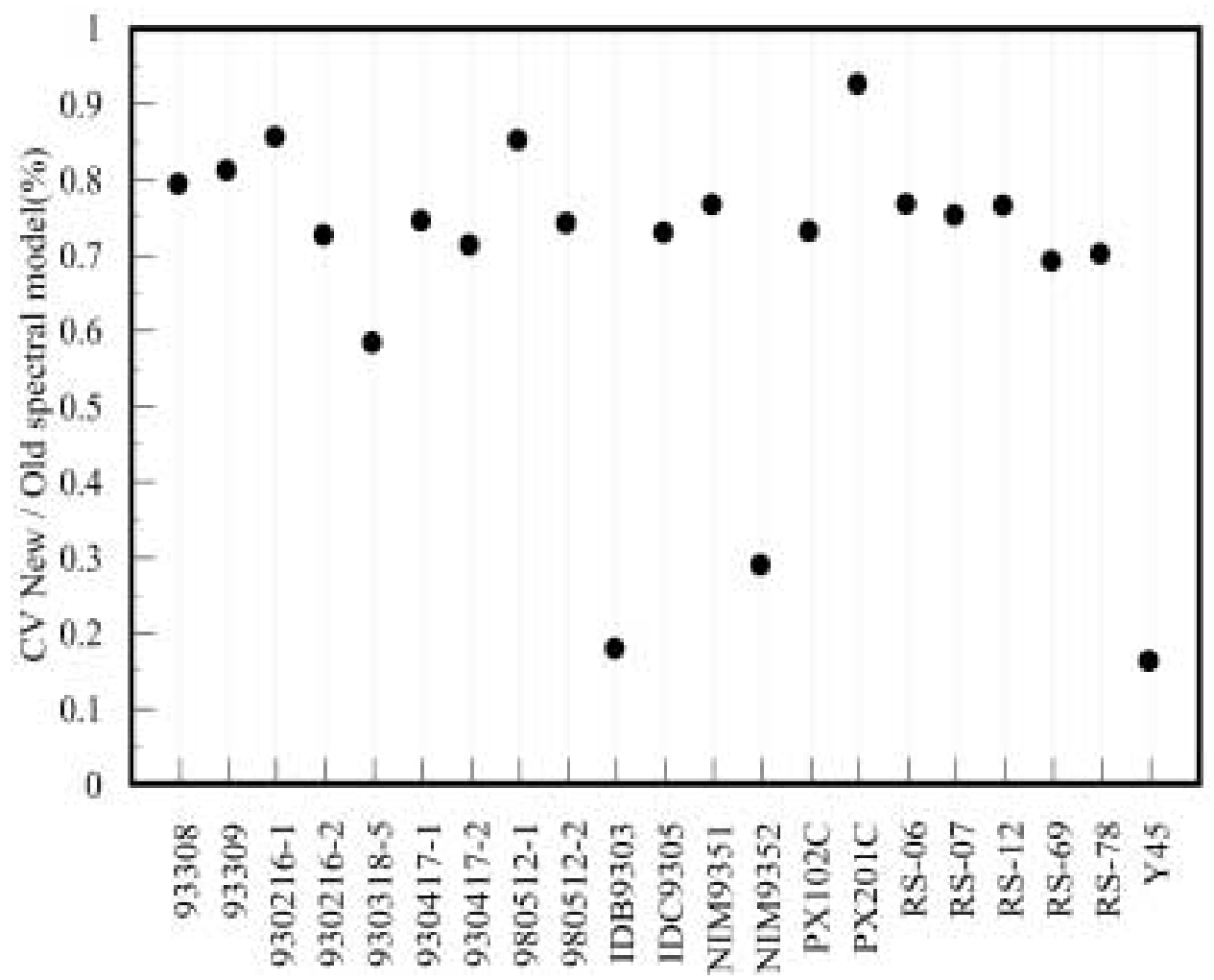

Figure 3. Percent change in the calibration value using the spectral model used for PEP 1993 versus spectral model used for PEP 1998. The WPVS determined $\mathrm{I}_{\mathrm{sc}}$ temperature coefficient and quantum efficiency were used along with the NREL 198 WPVS calibration data.

\subsection{Calibration values for WPVS cells}

The new WPVS calibration values were obtained by averaging all previous valid calibration values as discussed in the 1993 Final PEP meeting held in Golden, Colorado on March 4-8, 1996 [3]. Table 3 summarizes the results of the 1998 WPVS NREL calibration. These results are shown graphically in Figure 4.

Table 3. WPVS Calibration Values at $25^{\circ} \mathrm{C}$, IEC 904 Global Reference Spectrum.

(The previous calibration values were taken from [3].)

\begin{tabular}{|c|c|c|c|c|c|c|c|c|c|c|}
\hline ID & $\begin{array}{l}\text { NREL } \\
(\mathrm{mA})\end{array}$ & $\begin{array}{l}\text { JQA/ } \\
\text { ETL } \\
(\mathrm{mA})\end{array}$ & $\begin{array}{l}\text { PTB } \\
(\mathrm{mA})\end{array}$ & $\begin{array}{l}\text { TIPS } \\
(\mathrm{mA})\end{array}$ & $\begin{array}{l}\text { NREL } \\
\text { ' } 98 \\
(\mathrm{~mA})\end{array}$ & $(\mathrm{mA})$ & $(\%)$ & new WP & $(\%)$ & $\mathrm{d} /$ new $\mathrm{I}_{\mathrm{s}}$ \\
\hline$\overline{930216-1}$ & 122.9 & 124.1 & $\overline{121.98}$ & $\overline{124.17}$ & $\overline{122.02}$ & $\overline{123.29}$ & $\overline{0.85}$ & $\overline{123.03}$ & $\overline{0.87}$ & $-\overline{0.21}$ \\
\hline $930216-2$ & 123.2 & 124.4 & 121.99 & 124.27 & 122.23 & 123.47 & 0.91 & 123.22 & 0.91 & -0.20 \\
\hline $930417-1$ & 124.1 & 125.8 & 123.61 & 126.45 & 124.39 & 124.99 & 1.08 & 124.87 & 0.96 & -0.10 \\
\hline $930417-2$ & 122.2 & 123.9 & 121.45 & 124.87 & 122.41 & 123.11 & 1.27 & 122.97 & 1.13 & -0.11 \\
\hline 93308 & 126.5 & 126.1 & 125.32 & 127.52 & 124.67 & 126.36 & 0.72 & 126.02 & 0.87 & -0.27 \\
\hline 93309 & 126.7 & 125.9 & 125.15 & 127.78 & 125.08 & 126.38 & 0.89 & 126.12 & 0.90 & -0.21 \\
\hline
\end{tabular}




$\begin{array}{lrlrrlrlllr}\text { NIM 9351 } & 122.1 & 120.9 & 119.59 & 121.59 & 117.89 & 121.05 & 0.90 & 120.41 & 1.41 & -0.52 \\ \text { NIM 9352 } & 120.8 & 120.3 & 118.46 & 121.10 & 119.01 & 120.17 & 0.98 & 119.93 & 0.96 & -0.19 \\ \text { PX102C } & 116.2 & 117.5 & 116.09 & 118.40 & 115.63 & 117.05 & 0.94 & 116.76 & 0.98 & -0.24 \\ \text { PX201C } & 122.5 & 123.9 & 122.04 & 124.71 & {[122.23]} & 123.29 & 1.00 & 123.29 & - & 0.00 \\ \text { PTB RS-58 126.1 } & 126.7 & 124.80 & 128.82 & & 126.61 & 1.32 & 126.61 & 1.32 & -0.00 \\ \text { PTB RS-67 } 125.4 & 126.2 & 123.91 & 127.10 & & 125.65 & 1.08 & 125.65 & 1.08 & 0.00 \\ \text { PTB RS-68 125.1 } & 126 & 123.57 & 127.69 & & 125.59 & 1.37 & 125.59 & 1.37 & 0.00 \\ \text { PTB RS-69 125.6 } & 126.1 & 123.44 & 127.60 & 123.30 & 125.69 & 1.37 & 125.21 & 1.46 & -0.38 \\ \text { PTB RS-78 117.3 } & 117.7 & 115.80 & 119.19 & 116.49 & 117.50 & 1.19 & 117.30 & 1.10 & -0.17 \\ \text { TDB 9303 } & 133.8 & 136.5 & 133.24 & 135.05 & 134.17 & 134.65 & 1.08 & 134.55 & 0.95 & -0.07 \\ \text { TDC9305 } & 124.3 & 126.4 & 123.48 & 124.19 & 125.21 & 124.59 & 1.01 & 124.71 & 0.90 & 0.10 \\ \text { Y09 } & 93.4 & 94.08 & 93.26 & 94.35 & & 93.77 & 0.56 & 93.77 & 0.56 & 0.00 \\ \text { Y45 } & 126.5 & 126.8 & 126.93 & 129.86 & 125.45 & 127.52 & 1.23 & 127.11 & 1.29 & -0.33 \\ \text { Y124 } & 107.9 & 111.3 & 109.12 & 105.32 & 106.35 & 108.41 & 2.30 & 108.00 & 2.17 & -0.38\end{array}$

The data for Y124 was collected in December 1999. The change in the WPVS value for the recalibrated cells varied from a $0.5 \%$ drop for NIM9351 to a $0.1 \%$ increase for TDC9305. The average decrease in WPVS calibration values was $0.16 \%$.

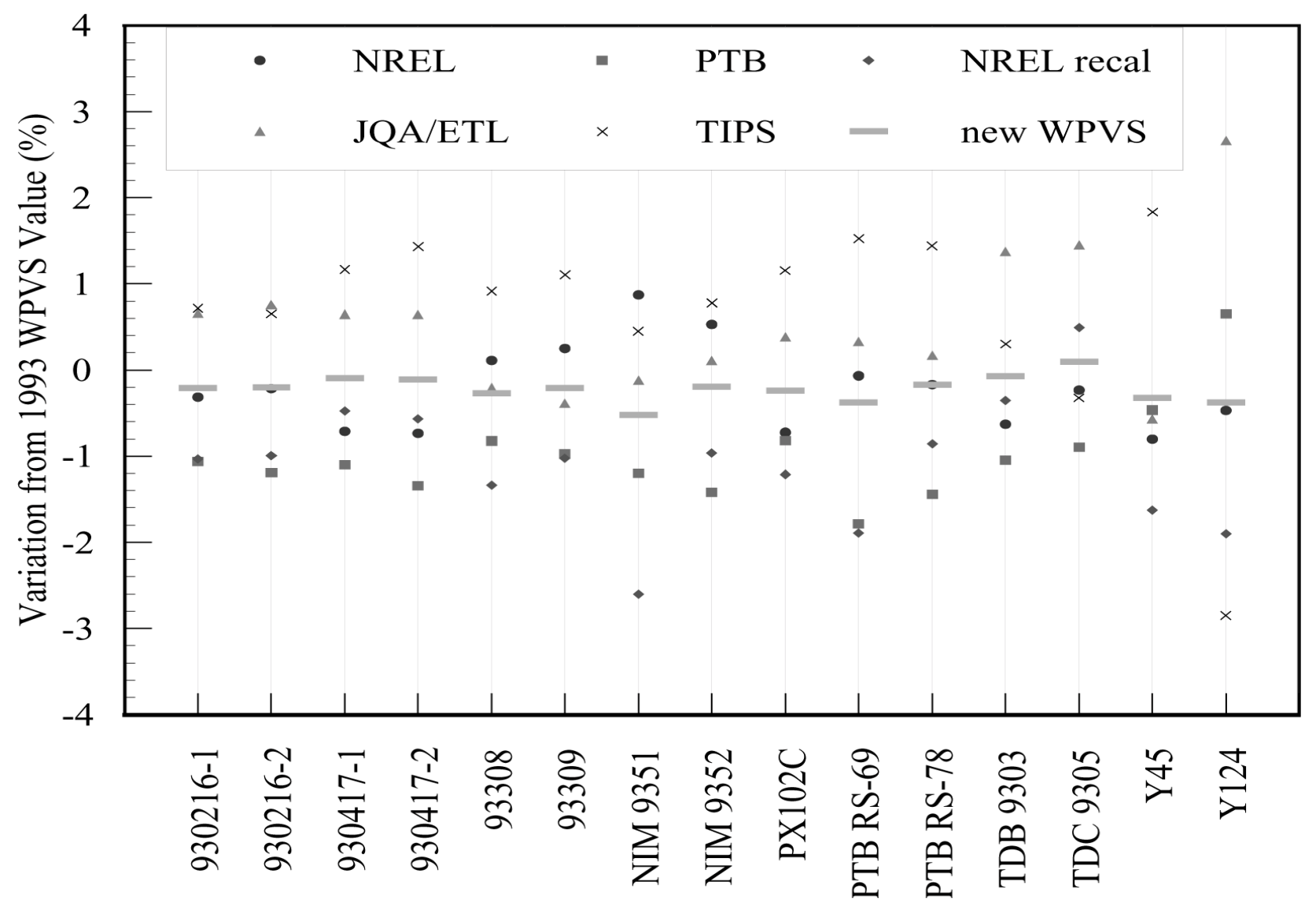

Figure 4. Comparison of previous and new WPVS calibration values for the cells that participated in the 1998 WPVS recalibration. 


\subsection{Calibration values for candidate WPVS cells}

The temperature coefficient for the five candidate WPVS cells is listed in Table 4 . The quantum efficiencies for these cells are shown in Figures 5-10. The package design is similar to the PRC Kochmann design described in reference 3. The cells exhibited no electrical or temperature sensor problems. Table 5 lists the calibration values assigned to these candidate cells using the supplied temperature coefficient and quantum efficiency. Table 6 gives the calibration values using the temperature coefficient measured at NREL (except RS-12) and the quantum efficiency measured at NREL. The differences are compared graphically in Figure 11. The supplied quantum efficiencies for the JQA cells 930318-5 and RS-12 appear too low (380 to $480 \mathrm{~nm}$ range). The supplied quantum efficiencies for $980512-1$ and 980512-2 appear to have large errors at 300 and $310 \mathrm{~nm}$. There was no significant difference between NREL and PTB, and the differences between NREL and Sandia were not significant for wavelengths greater than $320 \mathrm{~nm}$.

Table 4. Comparison of NREL's and the Supplied $I_{\text {sc }}$ Temperature Coefficients $\left(\mathrm{ppm} /{ }^{\circ} \mathrm{C}\right)$ Normalized at $25^{\circ} \mathrm{C}$.

\begin{tabular}{|c|c|c|c|c|}
\hline Sample ID & NREL & PTB & JQA & Sandia \\
\hline$\overline{930318-5}$ & 796 & & $\overline{890}$ & \\
\hline $980512-1$ & 642 & & & 589.5 \\
\hline $980512-2$ & 631 & & & 559.8 \\
\hline RS-06 & 627 & 590 & & \\
\hline RS-07 & 506 & 540 & & \\
\hline RS-12 & - & & 500 & \\
\hline
\end{tabular}




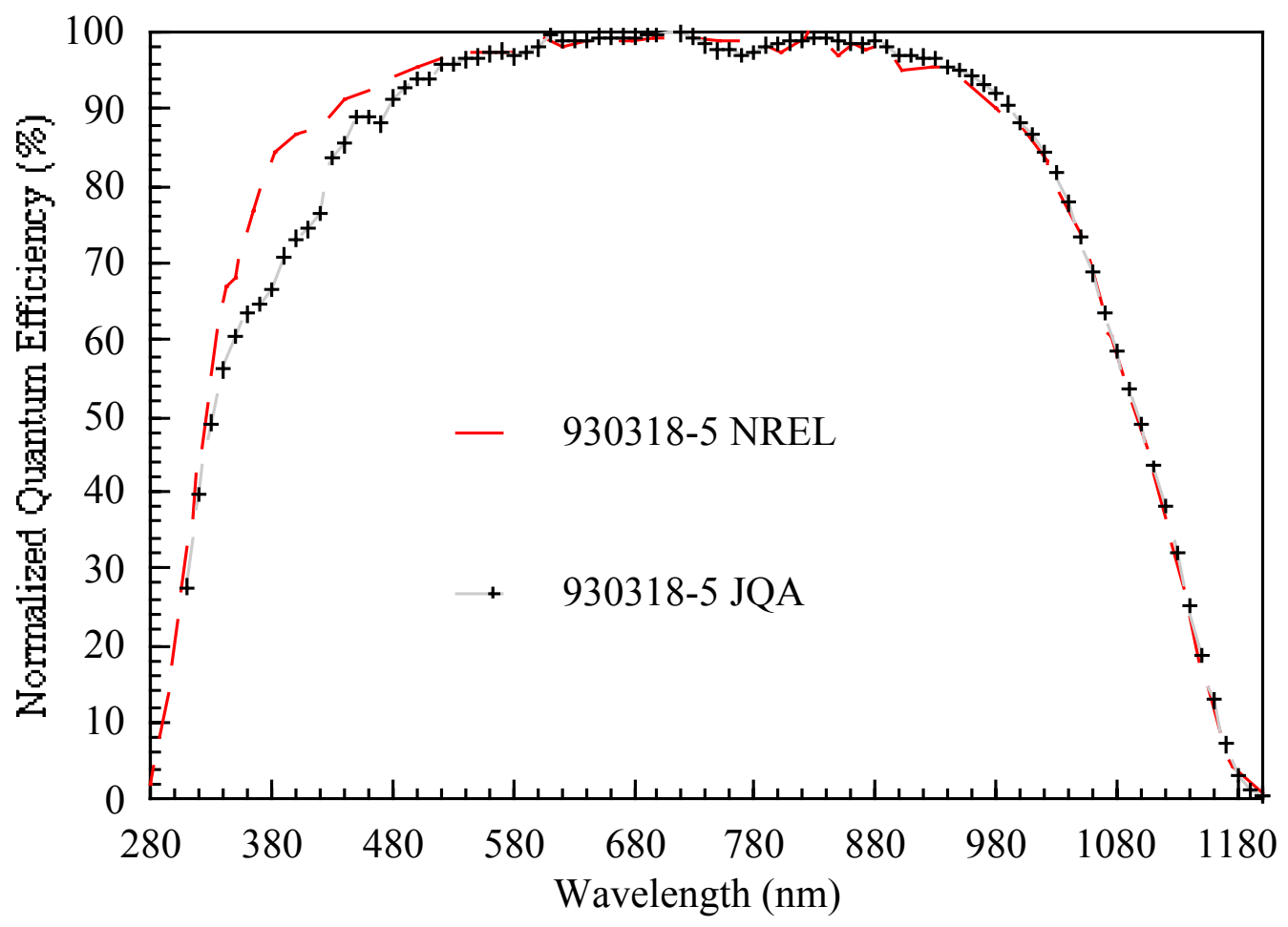

Figure 5. NREL and JQA QE on sample 930318-5.

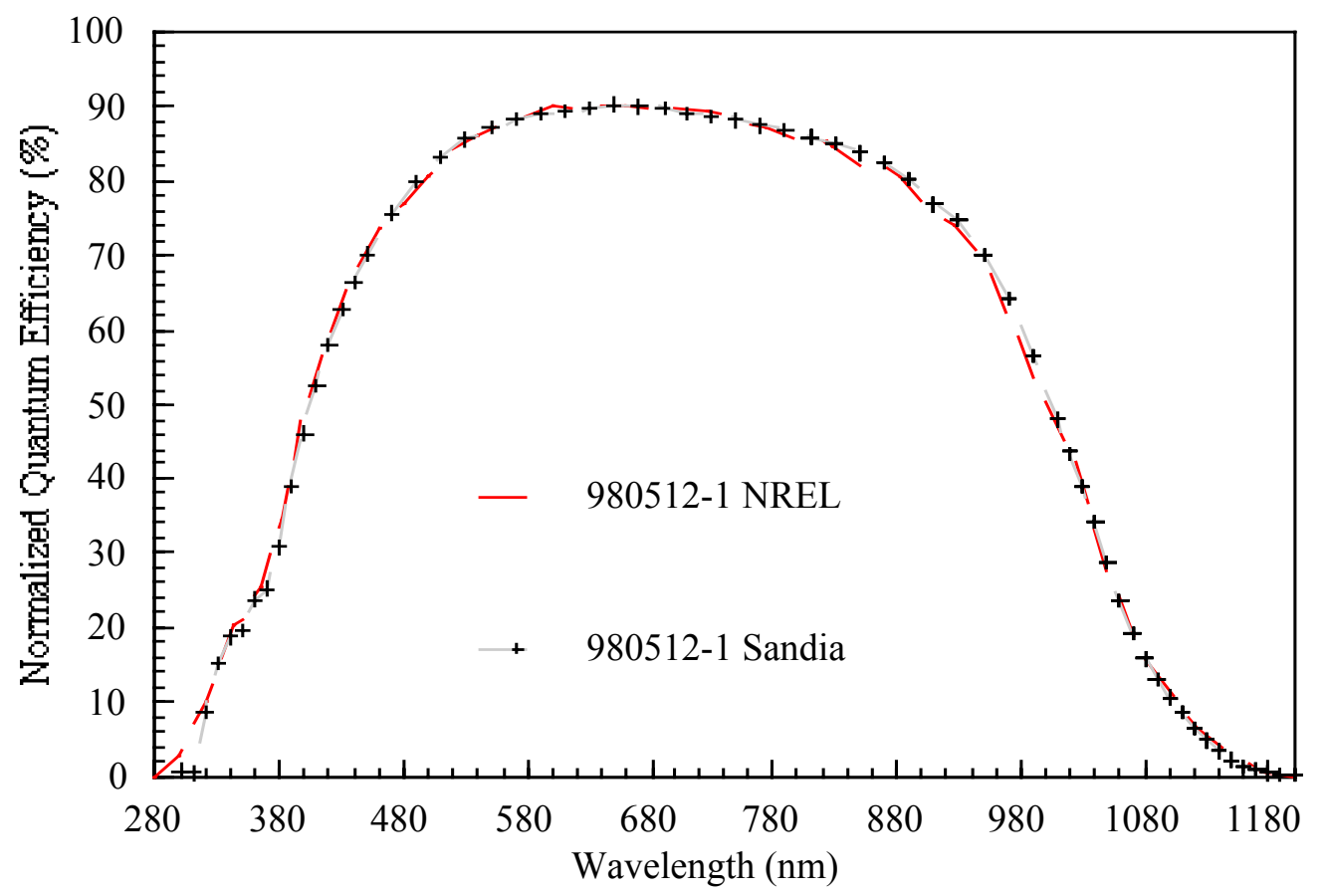

Figure 6. NREL and Sandia QE on sample 980512-1. 


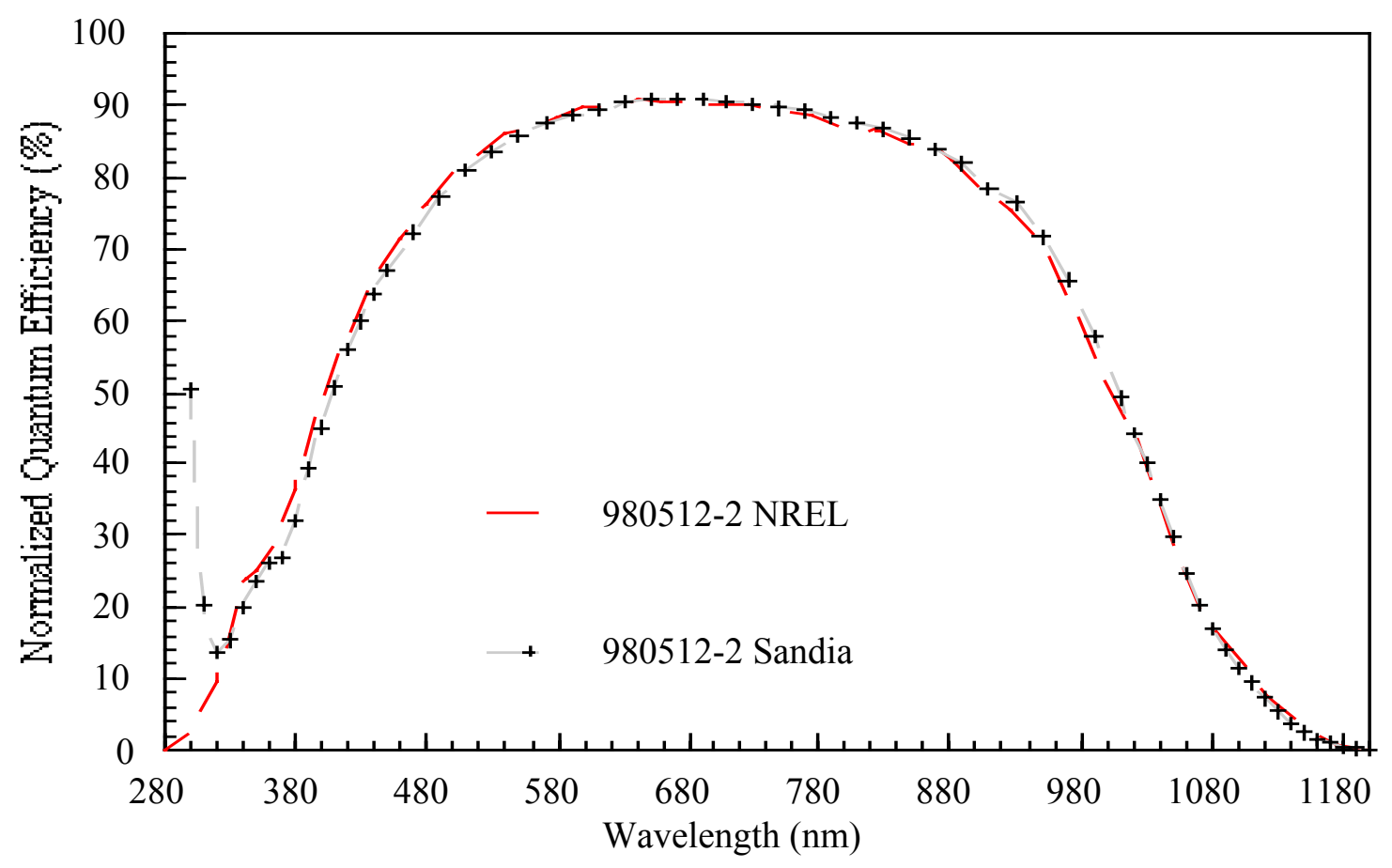

Figure 7. NREL and Sandia QE on sample 980512-2.

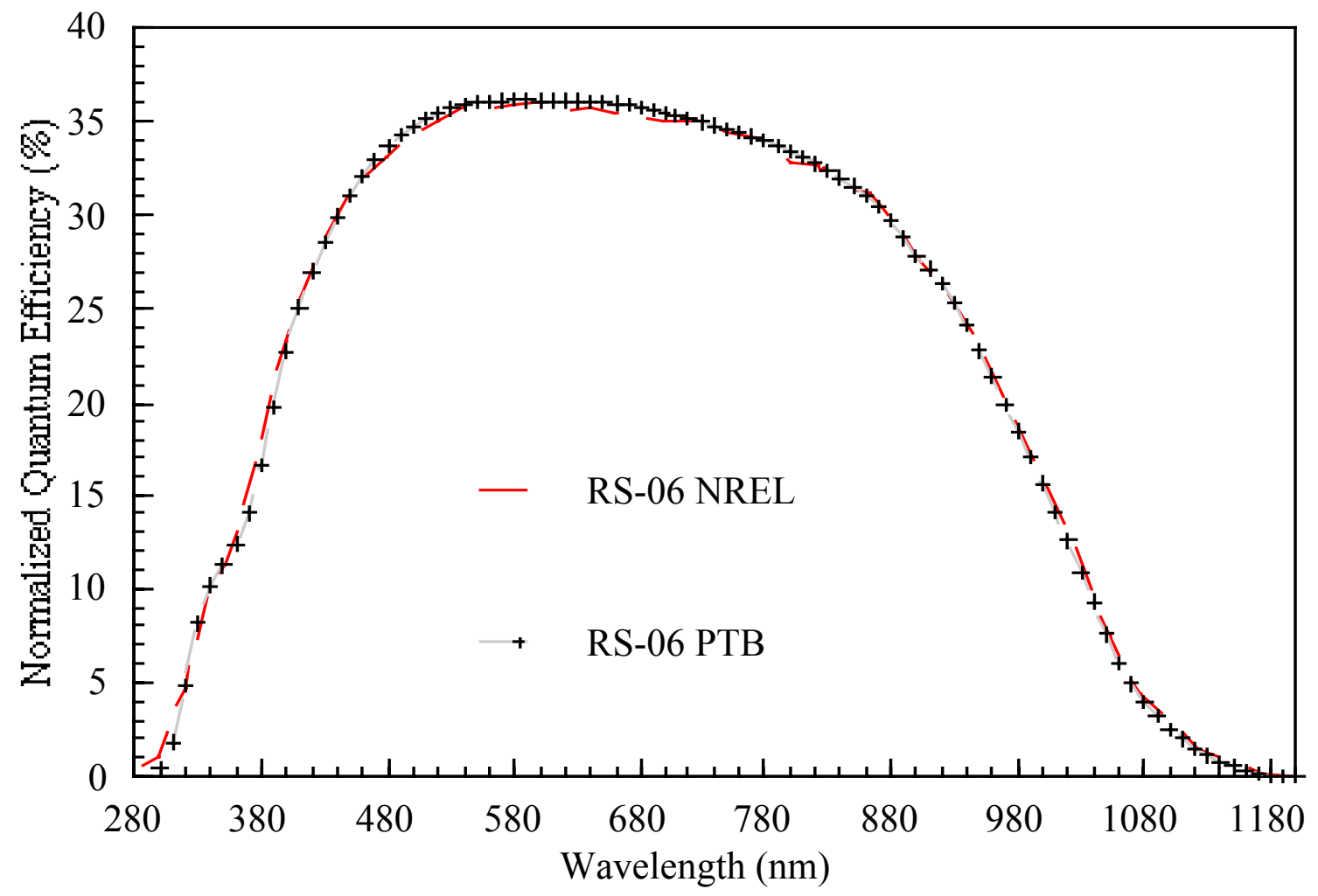

Figure 8. NREL and PTB QE on sample RS-06. 


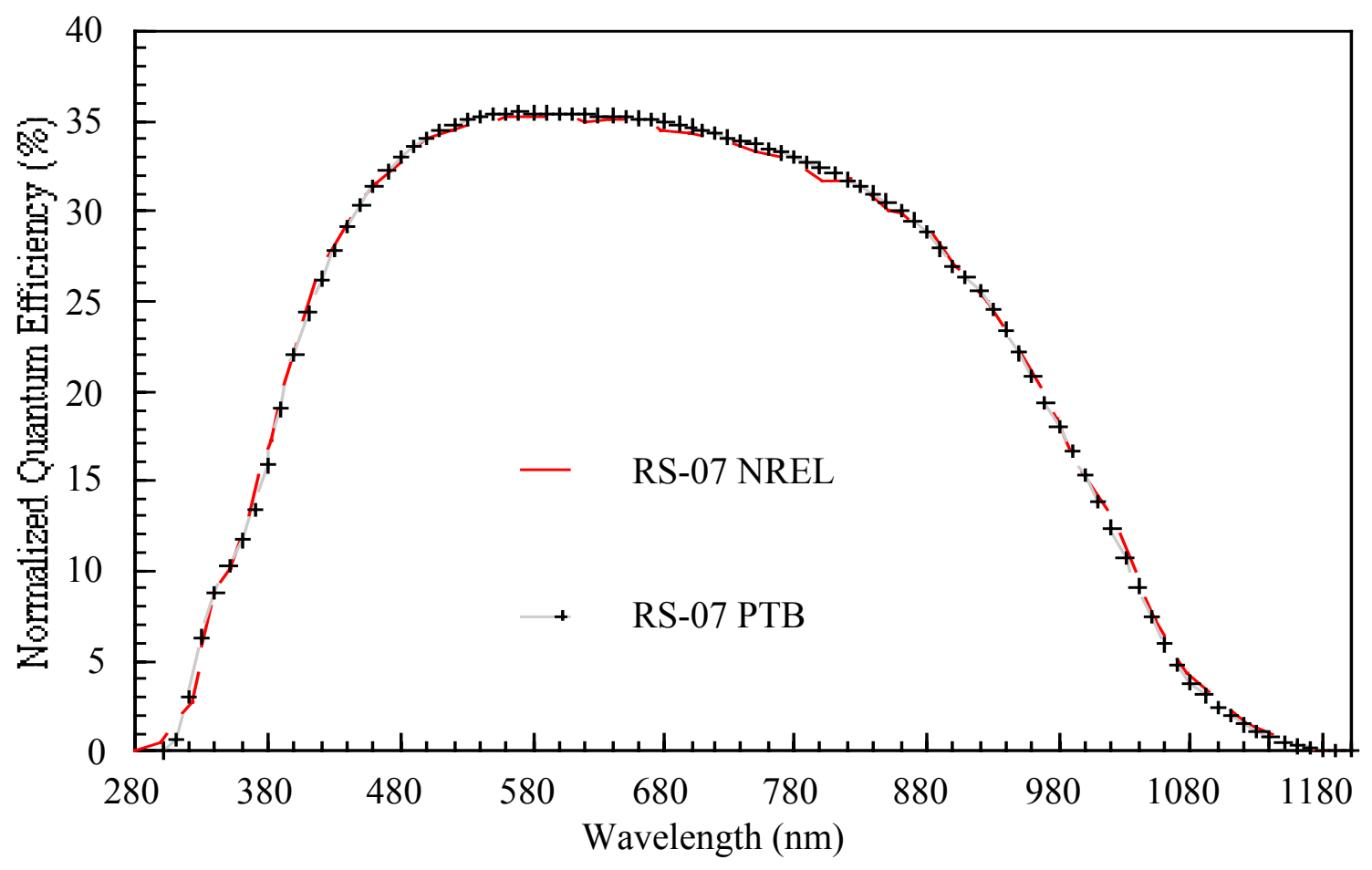

Figure 9. NREL and PTB QE on sample RS-07.

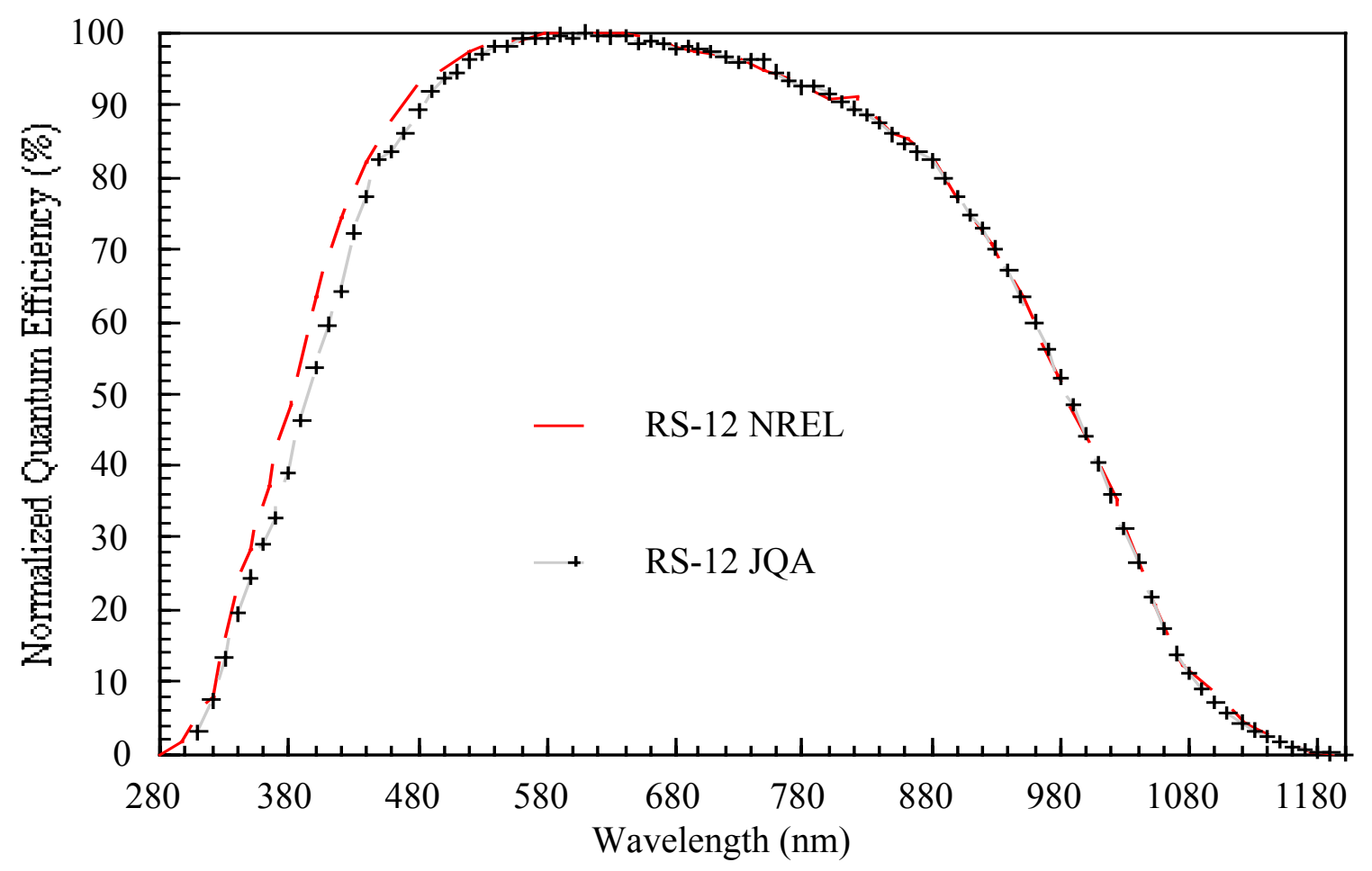

Figure 10. NREL and JQA QE on sample RS-12. 
Table 5. New WPVS Candidates Using the Supplied Spectral Responsivity and Temperature Coefficient.

$\begin{array}{lllll}\text { ID } & \text { Isc (mA) } & \sigma(\%) & \text { \# points } & \text { \# days } \\ \overline{930318-5} & \overline{138.05} & \overline{0.127} & \overline{37} & \overline{3} \\ 980512-1 & 122.34 & 0.352 & 34 & 3 \\ 980512-2 & 123.21 & 0.266 & 36 & 3 \\ \text { RS-06 } & 124.86 & 0.186 & 31 & 3 \\ \text { RS-07 } & 121.60 & 0.186 & 33 & 3 \\ \text { RS-12 } & 118.71 & 0.042 & 26 & 3\end{array}$

Table 6. New WPVS Candidates Using Spectral Responsivity and Temperature Coefficients Measured at NREL.

\begin{tabular}{lllll} 
ID & Isc (mA) & $\sigma(\%)$ & \# points & \# days \\
\hline 930318-5 & $\overline{138.58}$ & $\overline{0.126}$ & $\overline{37}$ & $\overline{3}$ \\
$980512-1$ & 122.43 & 0.361 & 34 & 3 \\
$980512-2$ & 123.38 & 0.337 & 36 & 3 \\
RS-06 & 124.85 & 0.187 & 31 & 3 \\
RS-07 & 121.61 & 0.192 & 33 & 3 \\
RS-12 & 118.97 & 0.124 & 26 & 3
\end{tabular}




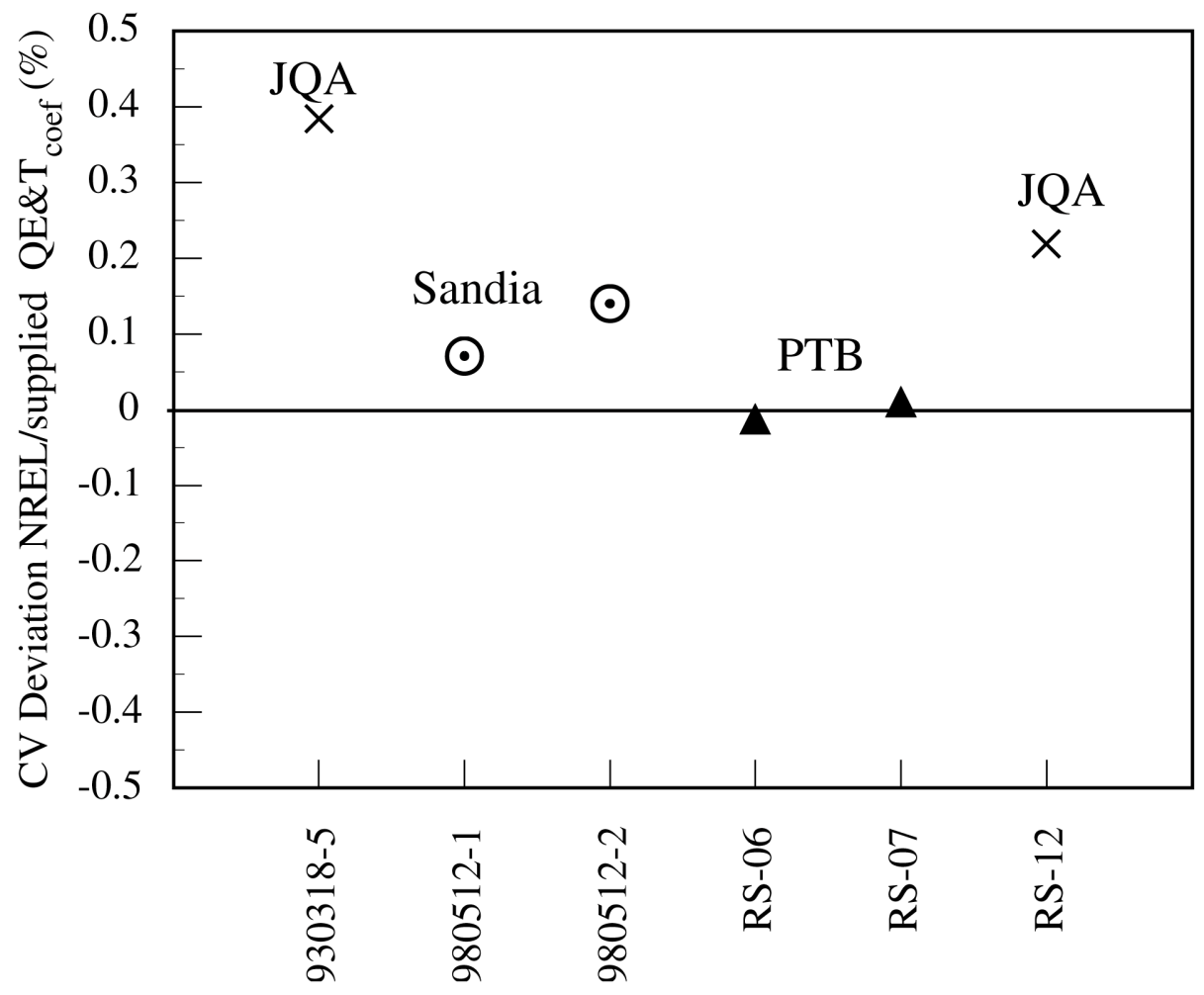

Figure 11. Percent variation in the calibration value using the NREL-measured versus supplied spectral response and temperature coefficients for the WPVS candidate cells. The differences are all due to variations in the spectral response.

\section{Summary and Recommendations}

The results of the first recalibration of WPVS reference cells have been presented. The WPVS calibration value was recomputed based upon the all of the valid WPVS calibration values shown in Table 3. The change in the WPVS value for the recalibrated cells varied from a $0.5 \%$ drop for NIM9351 to a $0.1 \%$ increase for TDC9305. The WPVS calibration values decreased by an average of $0.16 \%$. 


\section{References}

1. C.R. Osterwald, S. Anevsky, A.K. Barua, J. Dubard, K. Emery, D. King, J. Metzdorf, F. Nagamine, R. Shimokawa, N. Udayakumar, Y.X. Wang, W. Zaaiman, A. Zastrow, J. Zhang, "Results of the PEP 1993 Intercomparison of Reference Cell Calibrations and Newer Technology Performance Measurements," Proc. 25th IEEE Photovoltaic Specialists Conf., Washington D.C., May 13-17, 1996, pp. 1263-1266, IEEE, New York, 1996.

2 C.R. Osterwald, S. Anevsky, A.K. Barua, J. Dubard, K. Emery, D. King, J. Metzdorf, F. Nagamine, R. Shimokawa, N. Udayakumar, Y.X. Wang, T. Wittchen, W. Zaaiman, A. Zastrow, and J. Zhang, "Results of the PEP'93 Intercomparison of Reference Cell Calibrations and Newer Technology Performance Measurements," Proc. 26th IEEE PVSC Conf., Aneheim, CA. Sept. 29-Oct. 2, 1997, pp. 1209-1212, IEEE, New York, 1997.

3. C.R. Osterwald, S. Anevsky, A.K. Barua, J. Dubard, K. Emery, D. King, J. Metzdorf, F. Nagamine, R. Shimokawa, N. Udayakumar, Y.X. Wang, W. Zaaiman, A. Zastrow, J. Zhang, "The Results of the PEP 1993 Intercomparison of Reference Cell Calibrations and Newer Technology Performance Measurements: Final Report," March 1998, NREL tech. rep. NREL/TP-520-23477.

4. C. R. Osterwald, K. Emery, D. Myers, and R. Hart, "Primary Reference Cell Calibrations at SERI: History and Methods," Twenty-first IEEE PVSC, 1990, pp. 1062-1067.

5. I. Reda, T. Stoffel, and J. Treadwell, "Results of NREL Pyrheliometer Comparisons," NPC October 5-16, 1998 (NREL report TP-560-28028) and October 4-15, 1999 (NREL report TP-560-28029).

6. H. Field and K. Emery, "An Uncertainty Analysis of the Spectral Correction Factor," Proc. 23rd IEEE Photovoltaic Specialists Conf., Louisville, KY, May 1014, 1993, pp. 1180-1187, IEEE, New York, 1993.

7. C. Wehrli, 1985: Extraterrestrial Solar Spectrum. Physikalish-Meterologisches Observatorium and World Radiation Center Pub. 615, 7 pp. [available at ftp://ftp.pmodwrc.ch/pub/publications/pmod615.asc].

8. C. Osterwald and K. Emery, "Spectroradiometric Sun Photometry," Journal of Atmospheric and Oceanic Technology, September 2000. 